\title{
The influence of sense of coherence on emotional response in heart transplant recipients - a preliminary report
}

\author{
Irena Milaniak ${ }^{1,2}$, Ewa Wilczek-Rużyczka ${ }^{3}$, Karol Wierzbicki $^{1,4}$, Jerzy Sadowski ${ }^{1,4}$, Piotr Przybyłowski ${ }^{1}$ \\ ${ }^{1}$ Department of Cardiovascular Surgery and Transplantation, John Paul II Hospital, Krakow, Poland \\ ${ }^{2}$ Faculty of Health and Medical Science, Andrzej Frycz Modrzewski Krakow University, Poland \\ ${ }^{3}$ Faculty of Psychology and Humanities, Andrzej Frycz Modrzewski Krakow University, Poland \\ ${ }^{4}$ Jagiellonian University, Collegium Medicum, Krakow, Poland
}

Kardiochirurgia i Torakochirurgia Polska 2014; 11 (2): 220-224

\begin{abstract}
Introduction: The success of heart transplantation in prolonging life and well-being must be considered in reference to its psycho-social outcomes, which intrinsically affect the longterm post-transplant morbidity. Sense of coherence and emotional response to organ reception are important factors in this group of patients.

The aim of this study was to assess the contribution of sense of coherence to emotional response to transplantation in heart transplant recipients.

Material and methods: The study was conducted on a group of 46 heart transplant recipients. The following research tools were applied in the assessment of personal resources (sense of coherence) and emotional response to heart transplant surgery: the Sense of Coherence Questionnaire developed by Antonovsky (SOC-29) and the Transplant Effects Questionnaire (TxEQ). The data were analyzed statistically.

Results: Heart transplant recipients do not experience guilt toward the donors and have no difficulties in disclosing their identities as heart transplant recipients. The study reports good adherence to immunosuppressive treatment recommendations and both a moderate concern about and a sense of responsibility for the transplanted organs among the patients. Global SOC was associated with guilt toward the donor, concern about the transplanted heart, and disclosure of the recipient's identity. Conclusions: The strength of the patients' global sense of coherence is related to the level of their emotional response to the heart transplant surgery.

Key words: heart transplantation, emotional response, sense of coherence.
\end{abstract}

\section{Introduction}

Heart transplantation ( $\mathrm{HTx}$ ) is one of the most critical transplantation procedures of all due to its life-sustaining

\section{Streszczenie}

Wstęp: Sukces przeszczepiania serca w przedłużaniu życia i dobrego samopoczucia musi być rozważany również w odniesieniu do psychospołecznych aspektów zabiegu, które same w sobie mają wpływ na chorobowość w odległym okresie po przeszczepieniu. Poczucie koherencji oraz odpowiedź emocjonalna na zabieg przeszczepienia są ważnymi czynnikami w tej grupie pacjentów.

Celem pracy była ocena wpływu poczucia koherencji i strategii radzenia sobie ze stresem na odpowiedź emocjonalną na zabieg transplantacji u osób po przeszczepieniu serca.

Materiał i metody: Badania przeprowadzono wśród 46 biorców serca. W celu oceny odpowiedzi emocjonalnej na zabieg przeszczepienia serca oraz zasobów osobistych (poczucia koherencji) użyto następujących narzędzi badawczych: Kwestionariusza Odpowiedzi Emocjonalnej na Zabieg Przeszczepienia Narządu (TxEQ) oraz Kwestionariusza Orientacji Życiowej A. Antonovsky'ego (SOC-29). Dane zostały poddane analizie statystycznej. Wyniki: Biorcy przeszczepu serca nie mają poczucia winy wobec dawcy i trudności z ujawnieniem swojej tożsamości jako biorcy serca. Badanie wskazuje na dobry poziom przestrzegania zaleceń dotyczących leczenia immunosupresyjnego oraz umiarkowaną troskę o swoje przeszczepione serce, jak również odpowiedzialność za przeszczepione serce. Globalne poczucie koherencji wiązało się z poczuciem winy wobec dawcy, troską o przeszczepione serce oraz ujawnieniem faktu transplantacji. Wnioski: Siła poczucia koherencji jest związana z poziomem odpowiedzi emocjonalnej na przeszczep serca.

Słowa kluczowe: przeszczep serca, odpowiedź emocjonalna, poczucie koherencji.

function. HTx is an established therapy for end-stage heart diseases $[1,2]$. The impact and importance of psycho-social issues, the patient's education, and their general compli-

Address for correspondence: Irena Milaniak, PhD, MSN, John Paul II Hospital in Kraków, Department of Cardiovascular Surgery and Transplantation, Prądnicka 80, 31-202 Kraków, Poland, tel. +48 609746 673, e-mail: irenem@poczta.onet.pl 
ance with HTx guidelines cannot be overemphasized in the context of procedure success and patient survival. The success is based on survival and control of comorbid diseases; it is influenced by lifelong adherence to therapeutic regimens and by the quality of life (QoL) outcomes $[2,3]$.

Organ transplantation significantly improves the quality of life as well as the psycho-social situation of the patient. However, achieving the QoL of a healthy person is rare, and psychological symptoms may persist [4].

The transplant literature underscores that receiving a new heart may give rise to a new set of stressors, psychological challenges, and adaptive demands [5].

Antonovsky identified and advocated the use of sense of coherence (SOC) as a central part of his salutogenic approach that explains why some individuals stay healthy despite encountering major stressors, while others succumb to diseases associated with various self-care behaviors [6, 7]. In this model, health and disease form a continuum from 'ease' to 'disease', rather than being seen as a dichotomous variable. Whether an individual moves along this continuum from one end to the other depends on the encountered stressors and the available set of coping resources. According to Antonovsky, comprehensibility, manageability, and meaningfulness are the three components that constitute one's SOC. These elements express the extent to which one has a pervasive feeling of confidence that the confronted stimuli are structured and predictable (comprehensible), as well as worthy of engagement (meaningful), and that his or her resources are sufficient to meet the demands of life (manageable). The stronger the SOC, the more likely an individual is to be able to select appropriate coping strategies and, therefore, to move toward the 'ease' end of the continuum [7]. A high SOC level makes people believe in life's predictability and order, which in turn motivates them to be healthy and functional. Considering that the management of transplantation relies heavily on self-management practices, evaluating SOC may also prove valuable in this group of patients. The questionnaire for evaluating the psychological response to transplantation was constructed to assess different post-transplant psycho-social factors and reflects the subtle and complex emotional and behavioral processes of that period. The Transplant Effect Question-

Tab. I. Background characteristics of the research group

\begin{tabular}{|c|c|}
\hline Characteristics & Study sample $(n=46)$ \\
\hline Age & Mean: 52.36, median: 57, max: 68, min: 21 \\
\hline \multicolumn{2}{|l|}{ Gender (\%) } \\
\hline Male & 76.19 \\
\hline Female & 23.80 \\
\hline $\begin{array}{l}\text { Time since the trans- } \\
\text { plant surgery }\end{array}$ & $\begin{array}{l}\text { Mean: } 10.84 \text { years, median: } 11 \text { years, } \\
\text { max: } 18 \text { years, min: } 3 \text { months since HTx }\end{array}$ \\
\hline $\begin{array}{l}\text { Employment status } \\
\text { (pensioners) }(\%)\end{array}$ & 80.95 \\
\hline \multicolumn{2}{|l|}{ Place of residence (\%) } \\
\hline City/town & 64.28 \\
\hline Village & 35.71 \\
\hline
\end{tabular}

naire (TxEQ) assesses five conceptually coherent factors: concern about the transplanted organ, guilt toward the donor, disclosure of the recipient's identity, adherence to medical treatment, and responsibility toward family, medical staff, and the donor [8, 9].

The aim of the study was to estimate the influence of the SOC on the emotional response of heart transplant recipients to the conducted cardiac transplant.

We hypothesized the following results: the SOC level was related to emotional response to heart transplantation (guilt, disclosure, responsibility, adherence, concern about the transplanted organ).

\section{Material and methods \\ Participants}

The study was conducted at the Department of Cardiovascular Surgery and Transplantology of the John Paul II Hospital in Kraków, Poland from January to May 2011. Upon obtaining the approval of the Hospital's Institutional Review Board, HTx recipients were invited to the trial as prospective subjects. The inclusion criteria included age over 18 years and a minimum 3-month period after transplant surgery. The overall cohort included 198 patients; the preliminary sample consisted of 46 patients. Table I provides information about the sample.

\section{Instruments}

\section{Sense of Coherence, Polish version (SOC-29)}

The questionnaire consists of 29 seven-point Likerttype items measuring the subscales of comprehensibility, manageability, and meaningfulness. The higher the total SOC score, the stronger the sense of coherence. In this study, tertiles were used to estimate sense of coherence, so that a score of 29-87 represents a poor sense of coherence, 88-145 a moderate sense of coherence, and 146-203 a strong sense of coherence. The total range of the scale is $29-203$ points. Validity and reliability were confirmed in previous studies [7].

\section{Transplant Effect Questionnaire}

This 23-item scale was created specifically for measuring the emotional response considered important for transplant recipients [8]. The TxEQ consists of five subscales assessing: concern about the transplanted organ (six items), feelings of guilt toward the donor (five items), disclosure of transplantation (three items), medication adherence (five items), and perceived responsibility (four items). Participants are asked to respond to each item on a five-point Likert scale ranging from "strongly disagree" to "strongly agree" (score from 1 to 5). Subscale scores are expressed as a mean obtained by dividing the total score by the number of items ranging from 1 to 5 . Higher scores indicate greater concern about the transplanted organ, greater disclosure, greater feelings of guilt, greater responsibility, and better adherence-related behavior. TxEQ norm values are not available. Tertiles were used to estimate the emotional re- 
Tab. II. Factor loading in the Transplant Effect Questionnaire using Cronbach's $\alpha(n=46)$

\begin{tabular}{ll} 
Factor & Loading Cronbach $\alpha$ \\
Worry about transplant & 0.61 \\
\hline Guilt regarding donor & 0.63 \\
\hline Disclosure & 0.72 \\
\hline Medication adherence & 0.61 \\
\hline Responsibility & 0.63 \\
\hline
\end{tabular}

sponse, so that a score of 1-2.3 represents a low emotional response, 2.4-3.6 a moderate response and 3.7-5 a high level of emotional response.

The English and German versions of TxEQ have good psychometric parameters and are able to illustrate different emotional response types among post-transplant patients $[8,9,13]$. A Polish version was employed in this study. The original version of TxEQ was translated into Polish by two independent translators upon the author's permission (Prof. Newman). The accepted version was examined by medical professionals in order to verify the understanding of the content. The final Polish version was then used in a pilot research study conducted at the John Paul II Hospital Department of Cardiovascular Surgery and Transplantology among heart transplant recipients $(n=52)$. Reliability analysis was conducted to estimate the internal consistency of the scale using Cronbach's $\alpha$ (Table II).

\section{Statistical analysis}

The data were analyzed using the SPSS software, and the descriptive statistics were summarized by means and standard deviations for continuous measures. The groups were compared with regard to age and time since the transplantation surgery using Student's $t$-test. To perform a bivariate analysis of the dependent (emotional response factors: guilt, adherence, responsibility, concern about the transplanted organ, disclosure, and coping strategies) and

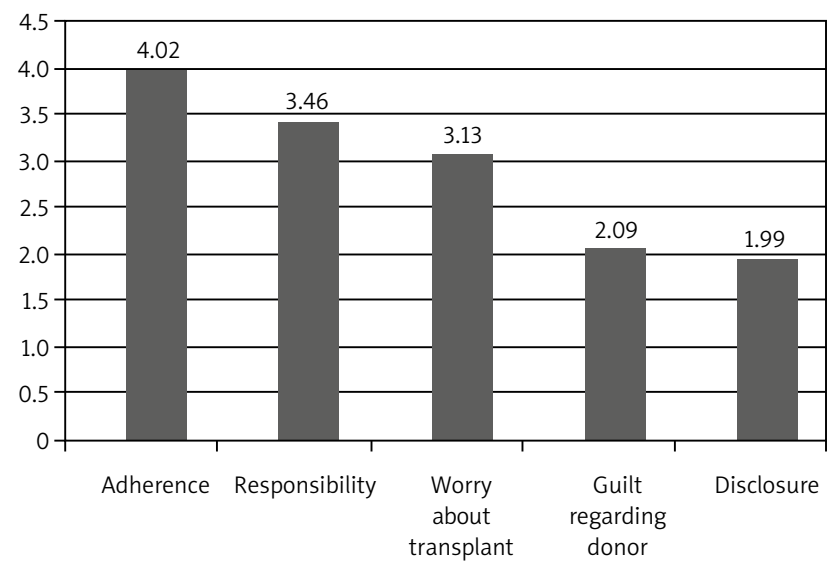

Fig. 1. Means of the Polish version of Transplant Effect Questionnaire (TxEQ) independent variables (sense of coherence, time since the transplantation surgery, and age of recipients), a Pearson correlation was conducted. Respective significance levels of $p<0.05$ and $p<0.01$ were predetermined for all the tests.

\section{Results}

The sample consisted of 46 participants: males (76.19\%) and females (23.80\%) who ranged in age from 21 to 68 . The mean age of all participants was 52.36 (SD 13.55).

The results of the Transplant Effect Questionnaire presented in Figure 1 demonstrate that HTx recipients exhibited little guilt toward the donor (avg. 2.09 - first tertile) and had some difficulty in disclosing their identity as HTx recipients (avg. 1.99 - first tertile). They reported good adherence to medication (avg. 4.02 - third tertile) and moderate responsibility for the transplanted heart (avg. 3.46 - second tertile) as well as moderate concern about their transplanted organ (avg. 3.13).

The SOC scores ranged from 59 to 189 (the highest possible score being 203); the mean was 135.21 (SD 18.38) (see Fig. 2). Most of the recipients reported a moderate sense of coherence $-67.39 \%$ scored in the second tertile.

\section{Verification of hypotheses \\ Correlations between SOC and emotional response}

Patients with low SOC scores exhibited negative attitudes with regard to guilt toward the donor $(r=-0.31$; $p<0.05)$ and concern about the transplanted organ $(r=-0.49 ; p<0.01)$. More specifically, there was a positive correlation between the patients' comprehensibility and their concern about the transplanted organ $(r=-0.42$; $p<0.01)$ as well as disclosure $(r=-0.34 ; p<0.05)$. The lower the comprehensibility score, the more the patients tend to worry about the transplanted organ and disclosure. We can also observe a statistical association between comprehensibility, guilt, and adherence $(r=-0.27 ; p=0.25)$. Furthermore, there was a significant negative correlation between manageability and concern about the transplanted organ

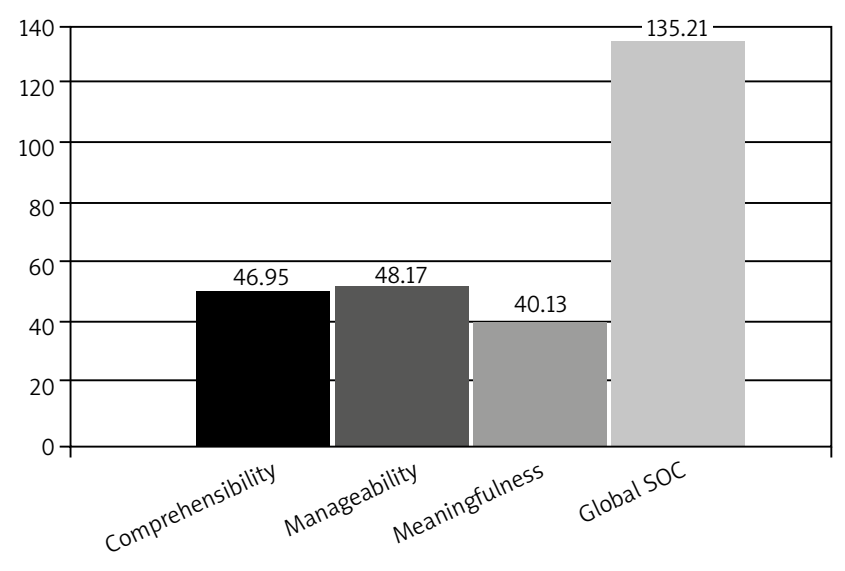

Fig. 2. The sense of coherence and its components in heart transplant recipients 
Tab. III. Correlation matrix of SOC and TxEQ

\begin{tabular}{|c|c|c|c|c|c|c|}
\hline & & Concern & Guilt & Disclosure & Responsibility & Adherence \\
\hline \multirow{3}{*}{ Comprehensibility } & Pearson & $-0.422^{\star \star}$ & -0.279 & $-0.345^{*}$ & 0.024 & 0.253 \\
\hline & Significance & 0.004 & 0.060 & 0.019 & 0.876 & 0.089 \\
\hline & $n$ & 46 & 46 & 46 & 46 & 46 \\
\hline \multirow{3}{*}{ Manageability } & Pearson & $-0.436^{\star \star}$ & -0.271 & -0.139 & -0.127 & 0.209 \\
\hline & Significance & 0.002 & 0.068 & 0.358 & 0.402 & 0.164 \\
\hline & $n$ & 46 & 46 & 46 & 46 & 46 \\
\hline \multirow{3}{*}{ Meaningfulness } & Pearson & $-0.408^{\star *}$ & -0.243 & -0.236 & -0.154 & 0.139 \\
\hline & Significance & 0.005 & 0.104 & 0.114 & 0.305 & 0.355 \\
\hline & $n$ & 46 & 46 & 46 & 46 & 46 \\
\hline \multirow{3}{*}{ Global SOC } & Pearson & $-0.496^{\star *}$ & $-0.311^{*}$ & -0.281 & -0.101 & 0.236 \\
\hline & Significance & 0.000 & 0.035 & 0.058 & 0.503 & 0.115 \\
\hline & $n$ & 46 & 46 & 46 & 46 & 46 \\
\hline
\end{tabular}

*Significant correlation at $p<0.05$

**Significant correlation at $p<0.01$

( $r=-0.43 ; p<0.01)$, as well as between meaningfulness and concern about the transplanted organ $(r=-0.40$; $p<0.01$ ), and a statistical association between guilt toward the donor and comprehensibility $(r=-0.27 ; p=0.06)$. The correlation matrix is presented in Table III.

\section{Discussion}

This study investigates the response of heart transplant recipients to their transplanted organs, the influence of the strength of their sense of coherence on their emotional response, and the coping strategies that they employed.

Admittedly, very little research has been devoted to this subject.

In order to assess emotional response, we translated the Transplant Effect Questionnaire (TxEQ) developed by Ziegelman [8]. In our study group, we found that heart transplant recipients experienced little guilt toward the donors (avg. = 2.09) and had some difficulty in disclosing their identities as heart transplant recipients (avg. $=1.99$ ). They reported good adherence (avg. $=4.02$ ), and their concern about their transplanted hearts was moderate (avg. = 3.13), as was their feeling of responsibility for the hearts (avg. = 3.46). Similarly to a study by Goetzman et al., our recipients were also moderately worried about their transplanted hearts and felt responsible toward family members, their treatment team, and the donor. We can notice some differences concerning the patients' feelings of guilt toward the donors (2.09 vs. 1.71 in the Goetzman study) and disclosing their identity as transplant recipients (1.99 vs. 3.42) [10]. In other studies, the recipients expressed some guilt regarding the death of the donor and were more reluctant to talk about their transplant experience [11, 12]. We conclude that the overwhelming majority of heart transplant recipients evinced mature psychological responses to the organ transplant surgery, and only a small percentage reported specific problems in handling the new situation after the transplant. As confirmed by Goetzman's study, this shows that the majority of the patients expressed positive experiences regarding their transplantation [13]. The patients spoke openly about their transplanted organs, while their statements about changes in their personal life were positive and expressed in the sense of personal growth.

Heart transplant recipients had average SOC (135) with respect to Antonovsky's norm (130-160) [7]. As SOC norms do not exist for transplant patients or the general population in Poland, a lower SOC does not necessarily mean that this population has a weak SOC. The results of Polish studies concerning SOC demonstrated that the strength of global SOC can be estimated at 118.75 for lung cancer patients [14], 113.5 for hypertensive patients [15], 144.9 for leukemic patients [16], and 146.12 for post-cardiac surgery patients [17].

Our results confirmed our hypothesis that the strength of sense of coherence is related to the emotional response to heart transplantation. We found that lower levels of sense of coherence and its components were associated with more feelings of guilt toward the donor, greater concern about the transplanted heart, and difficulties in disclosing one's identity as a cardiac transplant recipient. It is important to recognize that this emotional response is specific to transplantation and that a stronger SOC can have positive consequences for the subjective TXEQ results, as is the case with quality of life, which is strongly related to SOC (the stronger the SOC, the better the QoL) [18].

The hypothesis of a correlation between age, time since the transplantation, and emotional response proved invalid. This study found no significant associations between the time since the transplant surgery and the emotional response of the patients. Adjustment to transplantation is 
influenced by the adaptive task of each phase in the transplant procedure (evaluation phase, waiting list phase, posttransplant phase), personality factors, as well as the patient's ability to cope psychologically [19]. In some studies, the findings indicate normal long-term adjustment among heart transplant recipients [20].

The present study emphasizes the value of using tools for measuring the emotional concerns and worries of transplant recipients.

One limitation of the study is that it was a single-centre study and the size of the group was small, which calls for caution in generalizing the findings. The second limitation concerns the representativeness of the sample. The majority of the sample consisted of long-term recipients (avg. 11 years).

\section{Conclusions}

The level of global sense of coherence is related to emotional response to heart transplantation. The scores of comprehensibility are inversely related to the concern about the transplanted organ and disclosure. Inverse correlations were noted between: manageability and concern about the transplanted heart, manageability and guilt toward the donor, as well as meaningfulness and concern about the transplanted organ.

\section{Clinical relevance of the research}

1. The findings may provide suggestions to health professionals regarding the ways in which they can improve support for heart transplant recipients and their families.

2. Our results emphasize the need for intensified psychotherapeutic management of such patients within the framework of a multidisciplinary transplantation team in order to help the patients with their emotional response to transplantation.

\section{Disclosure}

The authors report no conflicts of interest.

\section{References}

1. D’Amico CL. Cardiac transplant: patient selection in the current era. J Cardiovasc Nurs 2005; 20: 504-513.

2. White-Williams C. Heart transplant over the life span. J Cardiovasc Nurs 2005; 20: 51-53.

3. De Geest S, Dobbels F, Fluir C, Paris W, Troosters T. Adherence to the therapeutic regimen in heart, lung and heart-lung transplant recipients. J Cardiovasc Nurs 2005; 20: 588-598.
4. Dew MA, Switzer GE, Goycoolea JM, Allen AS, DiMartini A, Kormos RL, Griffith BP. Does transplantation produce quality of life benefits. A quantities analysis of literature. Transplantation 1997; 15: 261-273.

5. Psychosocial Outcomes Workgroup of the Nursing and Social Sciences Council of the International Society for Heart and Lung Transplantation; Cupples S, Dew MA, Grady LK, De Geest S, Dobbels F, Lanuza D, Paris W. Report of the Psychosocial Outcomes Workgroup of the Nursing and Social Sciences Council of the International Society for Heart and Lung Transplantation: present status of research on psychosocial outcomes in cardiothoracic transplantation: review and recommendation for the field. J Heart Lung Transplant 2006; 25: 716-725.

6. Delgado C. Sense of coherence, spirituality, stress and quality of life in chronic illness. J Nurs Scholarsh 2007; 3: 229-234.

7. Antonovsky A. Rozwikłanie tajemnicy zdrowia. Jak radzić sobie ze stresem i nie zachorować. Instytut Psychiatrii i Neurologii, Warszawa 2005; pp. 31-45.

8. Ziegelmann JP, Griva K, Hankins M, Harrison M, Davenport A, Thompson D, Newman SP. The Transplant Effects Questionnaire (TxEQ): The development of a questionnaire for assessing the multidimensional outcome of organ transplantation - example of end stage renal disease (ESRD). Br J Health Psychol 2002; 7: 393-408.

9. Griva K, Ziegelmann JP, Thomspon D, Jayasena D, Davenport A, Harrison M, Newman SP. Quality of life and emotional responses in cadaver and living related renal transplant recipients. Nephrol Dial Transplant 2002; 17: 204-211.

10. Goetzman L, Sarac N, Ambübl P, Boehler A, Irani S, Muellhaupt B, Noll G, Schleuniger M, Schwegler K, Buddeberg C, Klaghofer R. Psychological response and quality of life after transplantation: a comparison between heart, lung, liver and kidney recipients. Swiss Medical Weekly 2008; 138: 477-483.

11. Inspector Y, Kutz I, David D. Another person's heart: magical and rational thinking in the psychological adaptation to heart transplantation. Isr J Psychiatry Relat Sci 2004; 41: 161-173.

12. Kaba E, Thompson DR, Burnard P, Edwards D, Theodosopoulou E. Somebody else's heart inside me: a descriptive study of psychological problems after a heart transplantation. Issues Ment Health Nurs 2005; 26: 611-625.

13. Goetzmann L, Lieberherr M, Krombholz L, Ambühl P, Boehler A, Noll G, Muellhaupt B, Wagner R, Buddeberg C, Klaghofer R. Subjective experiences following organ transplantation - a qualitative study of 120 heart, lung, liver, and kidney recipients. Z Psychosom Med Psychother 2010; 56: 268-282.

14. Kurowska K, Weilandt K. Sense of coherence and doping with the diseases in patient with diagnosis of lung cancer. Nursing Topics 2010; 1: 11-16.

15. Kurowska K, Dabrowska A. The sense of coherence and styles of coping with disease in patients with diagnosed arterial hypertension. Arterial Hypertension 2008; 12: 432-438.

16. Jabłoński M. Poczucie koherencji a ryzyko rozwoju depresji u chorych na ostrą białaczkę. Psychoonkologia 2009; 1-2: 1-10 [in Polish].

17. Kurowska K, Trzeciak D, Głowacka M, Ponczek D. Poczucie koherencji a zachowania zdrowotne osób kwalifikowanych do zabiegu kardiochirurgicznego. Pielęgniarstwo Chirurgiczne i Angiologiczne 2010; 4: 130-135 [in Polish].

18. Eriksson M, Lindström B. Antonovsky's sense of coherence scale and its relation with quality of life: a systematic review. J Epidemiol Community Health 2007; 61: 938-944.

19. Rivard AL, Hellmich C, Sampson B, Bianco RW, Crow SJ, Miller LW. Preoperative predictors for postoperative problems in heart transplantation: psychiatric and psychosocial considerations. Prog Transplant 2005; 15: 276-282.

20. Rybarczyk B, Grady KL, Naftel DC, Kirklin JK, White-Williams C, Kobashigawa J, Chait J, Young JB, Pelegrin D, Czerr J, McLeod M, Rissinger J, Higgins R, Heroux A. Emotional adjustment 5 years after heart transplant: A multisite study. Rehabilitation Psychology 2007; 52: 206-214. 